\title{
Genotypic Correlation Coefficients among Growth, Yield and Quality Parameters in Amaranthus Genotypes (Amaranthus tricolor L.)
}

\author{
K.P. Sagar, C.N. Hanchinamani, S.J. Imamsaheb*, \\ Sandhyarani Nishani and S.H. Ramanagouda
}

Dept. of Vegetable Science, K. R. C. College of Horticulture, Arabhavi - 591218

*Corresponding author

\section{A B S T R A C T}

Keywords

Amaranthus,

Correlation,

Coefficients and

genotypes

Article Info

Accepted:

15 July 2018

Available Online:

10 August 2018
In the present study, foliage yield per plant was significantly and positively correlated with stem girth, number of leaves per plant, number of branches per plant, spike length, number of spikes per plant at both phenotypic and genotypic level. Yield per plant was also positively and significantly correlated with leaf area only at genotypic level. Negative and significant correlation was also found for calcium and iron content of leaves with foliage yield per plant at both phenotypic and genotypic level whereas, hypocotyl length exhibited negative and significant association with foliage yield per plant only at genotypic level.

\section{Introduction}

Amaranthus or chaulai (Amaranthus tricolor) is a very popular leafy vegetable in India as well as in tropical and sub-tropical areas of globe. It is growing throughout the year since it has very quick growth and larger produce of edible matter per unit area and it suited for crop rotation. The word "Amaranth" is basically derived from Greek word "Anthos" which means "everlasting" according to Sankaran (1943). The genus Amaranthus includes 50-60 species, cultivated for leaf as well as for grains and few are wild species. The vegetable amaranth species $(2 \mathrm{n}=34)$ include A. tricolor, A. dubius, A. lividus, A. blitum, A. tristis, and A. viridis, while grain types $(2 \mathrm{n}=32)$ includes $A$. cruentus $A$. caudatus and $A$. spinosus. The diversity of amaranth are Central and South America, India and South East Asia with secondary centres of diversity in West and East Africa. Main vegetable type of leaf amaranth is $A$. tricolor, originated in south East Asia, particularly in India (Rai and Yadav, 2005). It is an important vegetable cultivated in India and other cultivars are available in India especially in Tamil Nadu, Andhra Pradesh, Karnataka and Kerala states. 
Tender stems and leaves contains higher moisture $(85.70 \%)$, protein $(4.0 \mathrm{~g})$, fat $(0.50$ $\mathrm{g})$, carbohydrates $(6.30 \mathrm{~g})$, calcium (397.0 $\mathrm{mg}$ ), iron (25.5mg), phosphorus (83.0 mg), vitamin A (9200 IU) and vitamin C (99 mg), (Rai and Yadav, 2005). It is also a good source of dietary fiber.

Yield is a complex character and is governed by polygenic system. Moreover, it is highly influenced by environmental fluctuations. Correlation study measures the natural relationship between various characters and helps in determining the component characters on which selection can be based for yield improvement. Correlation coefficient measures the degree of association either in positive or negative direction. Genotypic correlation is the inherent association between two variables and it may be either due to pleiotropic action of genes or linkage or both. In view of the above facts, the present studies entitled Genotypic Correlation Coefficients among Growth, Yield and Quality parameters in Amaranthus genotypes (Amaranthus tricolor L.) was undertaken.

\section{Materials and Methods}

The investigation was carried out at Kittur Rani Channamma College of Horticulture, Arabhavi, Belagavi district (Karnataka) during kharif 2017. The details of the experiment, materials used and techniques adopted in present investigation are presented in this chapter. Study comprised of twenty five genotypes the details given in Table 1 with two replications. The designed adopted for study is randomized block design. Each treatment or genotype in a replication was represented by a row of 5.00 meter length with 25 plants. All the cultural practices were carried out to manage the crop. The data were recorded on five competitive fertile plants for growth, yield and quality parameters.
The data was analysed using INDOSTAT software programme. For the analysis of the data the following statistical methods were employed, namely analysis of variance, genetic parameters viz., genotypic and environmental variance, environmental coefficient of variation (Burton and Devane, 1952) and classified (high/medium/low) as suggested by Sivasubramanian and Madhavamenon (1973).

\section{Results and Discussion}

Variability studies provide information on the extent of improvement in different characters, but they do not throw light on the extent and nature of relationship existing between various characters. Therefore, for rational approach towards the improvement of yield, selection has to be made for the components of yield, since there may not be genes for yield per se, but only for various yield components (Grafius, 1959). Genetic correlations between two characters arise because of linkage, pleiotrophy or developmentally induced functional relationship (Harland, 1939). Hence, it has greater significance and could be effectively utilized in formulating an effective selection scheme. Many of these yield contributing characters are interacted in desirable and undesirable direction. Hence, knowledge of association between the traits can greatly help in avoiding inversely related compensation effects during selection. A narrow difference between the genotypic and phenotypic correlation coefficients was observed for various traits in the present findings and thus indicates the lesser influence of environment in the expression of these traits and presence of strong inherent association among the traits. Therefore, in the present study only the heritable genotypic association has been discussed.

In the present study, foliage yield per plant exhibited highly significant and positive 
association with number of leaves per plant (0.987) followed by stem girth (0.696), number of branches per plant (0.631), number of spikes per plant (0.629), spike length $(0.566)$ and leaf area $(0.355)$. This vividly suggests the possibility of simultaneous improvement of these traits in improving total foliage yield per plant. Similar results were reported by earlier workers viz., Jangde et al., (2017), Buhroy et al., (2017), Sarker et al., (2014), Tejaswini et al., (2017), Chattopadhyay et al., (2013), Sarker et al., (2016), Buhroy et al., (2017), Diwan et al.,
(2017), Sarker et al., (2016) and Chattopadhyay et al., (2013) for stem girth, Varalakshmi and Devaraju (2010), Ahammed et al., (2012), Buhroy et al., (2017) and Sarker et al., (2016) for number of branches per plant, Yashwanth (2009) and Singh (2010) for spike length and Sravanti (2011), Sarker et al., (2014) and Roni (2013) for leaf area. While, plant height, days to flower initiation and 50\% flowering, harvest index, protein, iron and oxalate content of leaves had no significant association with foliage yield per plant.

Table.1 Details of amaranthus genotypes included in the study.

\begin{tabular}{|r|l|l|}
\hline Sl. No. & \multicolumn{1}{|c|}{ Genotypes } & \multicolumn{1}{|c|}{ Source } \\
\hline $\mathbf{1}$ & HUB-1 & K.R.C. College of Horticulture, Arabhavi. \\
\hline $\mathbf{2}$ & HUB-2 & K.R.C. College of Horticulture, Arabhavi. \\
\hline $\mathbf{3}$ & HUB-3 & K.R.C. College of Horticulture, Arabhavi. \\
\hline $\mathbf{4}$ & HUB-4 & K.R.C. College of Horticulture, Arabhavi. \\
\hline $\mathbf{5}$ & HUB-5 & K.R.C. College of Horticulture, Arabhavi. \\
\hline $\mathbf{6}$ & HUB-6 & K.R.C. College of Horticulture, Arabhavi. \\
\hline $\mathbf{7}$ & HUB-7 & K.R.C. College of Horticulture, Arabhavi. \\
\hline $\mathbf{8}$ & HUB-8 & K.R.C. College of Horticulture, Arabhavi. \\
\hline $\mathbf{9}$ & HUB-9 & K.R.C. College of Horticulture, Arabhavi. \\
\hline $\mathbf{1 0}$ & HUB-10 & K.R.C. College of Horticulture, Arabhavi. \\
\hline $\mathbf{1 1}$ & HUB-11 & K.R.C. College of Horticulture, Arabhavi. \\
\hline $\mathbf{1 2}$ & HUB-12 & K.R.C. College of Horticulture, Arabhavi. \\
\hline $\mathbf{1 3}$ & HUB-13 & K.R.C. College of Horticulture, Arabhavi. \\
\hline $\mathbf{1 4}$ & HUB-14 & K.R.C. College of Horticulture, Arabhavi. \\
\hline $\mathbf{1 5}$ & HUB-15 & K.R.C. College of Horticulture, Arabhavi. \\
\hline $\mathbf{1 6}$ & HUB-16 & K.R.C. College of Horticulture, Arabhavi. \\
\hline $\mathbf{1 7}$ & HUB-17 & K.R.C. College of Horticulture, Arabhavi. \\
\hline $\mathbf{1 8}$ & HUB-18 & Local collection from Yallapur village \\
\hline $\mathbf{1 9}$ & HUB-19 & Local collection from Upparahatti village. \\
\hline $\mathbf{2 0}$ & HUB-20 & Local collection from Duradundi village. \\
\hline $\mathbf{2 1}$ & HUB-21 & Local collection from Gokak. \\
\hline $\mathbf{2 2}$ & HUB-22 & Local collection from Ghataprabha. \\
\hline $\mathbf{2 3}$ & HUB-23 & Local collection from Ghataprabha. \\
\hline $\mathbf{2 4}$ & Arka Samraksha & IIHR, Bengaluru. \\
\hline $\mathbf{2 5}$ & Arka Varna & IIHR, Bengaluru. \\
\hline & & \\
\hline
\end{tabular}


Table.2 Genotypic correlation coefficients among growth, earliness, yield and quality parameters in amaranthus (Amaranthus tricolor)

\begin{tabular}{|c|c|c|c|c|c|c|c|c|c|c|c|c|c|c|c|c|c|}
\hline & $\mathrm{PH}$ & SG & NBP & NLP & DFI & DFF & SL & NSP & HI & LA & HL & PR & $\mathrm{CA}$ & IR & PHE & OX & FYP \\
\hline PH & 1.000 & $0.485^{* *}$ & $0.751 * *$ & $0.558 * *$ & -0.080 & 0.050 & $0.309 *$ & $0.550 * *$ & -0.005 & $0.357^{*}$ & $-0.344 *$ & -0.047 & -0.232 & $-0.347 *$ & -0.113 & $-0.780 * *$ & 0.014 \\
\hline SG & & 1.000 & $0.561 * *$ & $0.726 * *$ & 0.049 & -0.013 & $0.869 * *$ & $0.494 * *$ & 0.128 & 0.617 ** & -0.224 & 0.267 & $-0.334 *$ & 0.087 & $-0.575 * *$ & $-0.373 * *$ & $0.696^{* * *}$ \\
\hline NBP & & & 1.000 & $0.801 * *$ & $-0.367 * *$ & $-0.284 *$ & $0.595 * *$ & $0.677 * *$ & -0.094 & 0.617 ** & -0.245 & -0.022 & $-0.486 * *$ & -0.218 & $-0.322 *$ & $-0.576^{* * *}$ & $0.631 * *$ \\
\hline NLP & & & & 1.000 & -0.153 & -0.046 & $0.565 * *$ & $0.780 * *$ & -0.149 & 0.499 ** & $-0.381 * *$ & 0.138 & $-0.307^{*}$ & -0.050 & $-0.368 * *$ & $-0.363 * *$ & $0.987 * *$ \\
\hline DFI & & & & & 1.000 & $0.968 * *$ & -0.018 & -0.126 & 0.027 & -0.187 & 0.039 & 0.143 & $0.331^{*}$ & -0.064 & -0.067 & 0.097 & -0.006 \\
\hline DFF & & & & & & 1.000 & -0.147 & 0.006 & -0.133 & -0.084 & $-0.304 *$ & 0.112 & 0.244 & -0.214 & -0.068 & 0.140 & -0.033 \\
\hline SL & & & & & & & 1.000 & $0.353^{*}$ & $0.370^{* * *}$ & $0.537 * *$ & $-0.349 *$ & 0.060 & $-0.308^{*}$ & 0.038 & $-0.591 * *$ & $-0.408 * *$ & $0.566^{* *}$ \\
\hline NSP & & & & & & & & 1.000 & -0.300 & $0.278^{*}$ & -0.203 & -0.239 & $-0.314^{*}$ & $-0.296^{*}$ & -0.210 & $-0.387 * *$ & $0.629 * *$ \\
\hline $\mathrm{HI}$ & & & & & & & & & 1.000 & 0.111 & 0.122 & 0.044 & $0.326^{*}$ & 0.037 & 0.059 & -0.102 & -0.127 \\
\hline LA & & & & & & & & & & 1.000 & $-0.322 *$ & $0.582 * *$ & $-0.275^{*}$ & 0.050 & $-0.364 * *$ & -0.183 & $0.355^{*}$ \\
\hline HL & & & & & & & & & & & 1.000 & -0.239 & 0.183 & -0.205 & 0.093 & 0.134 & $-0.338^{*}$ \\
\hline PR & & & & & & & & & & & & 1.000 & 0.023 & $0.343^{*}$ & $-0.331 *$ & 0.128 & 0.160 \\
\hline $\mathrm{CA}$ & & & & & & & & & & & & & 1.000 & -0.035 & 0.224 & $0.317 *$ & $-0.518^{* * *}$ \\
\hline IR & & & & & & & & & & & & & & 1.000 & -0.212 & 0.242 & 0.184 \\
\hline PHE & & & & & & & & & & & & & & & 1.000 & 0.265 & $-0.693 * *$ \\
\hline OX & & & & & & & & & & & & & & & & 1.000 & -0.057 \\
\hline FYP & & & & & & & & & & & & & & & & & 1.000 \\
\hline
\end{tabular}

Critical $r_{\mathrm{g}}$ value $=0.278$ at $5 \%$ and 0.361 at $1 \% *$ and $* *$ indicate significant at 5 and 1 per cent probability level, respectively.

$\mathrm{PH}=$ Plant height $(\mathrm{cm})$

$\mathrm{SG}=$ Stem girth $(\mathrm{mm})$

$\mathrm{NBP}=$ Number of branches/plant

$\mathrm{NLP}=$ Number of leaves/plant

DFI=Days to flower initiation

$\mathrm{DFF}=$ Days to $50 \%$ flowering
$\mathrm{SL}=$ Spike length $(\mathrm{cm})$

$\mathrm{NSP}=$ Number of spikes/plant

$\mathrm{HI}=$ Harvest index $(\%)$

$\mathrm{LA}=$ Leaf area $\left(\mathrm{cm}^{2}\right)$

$\mathrm{HL}=$ Hypocotyl length $(\mathrm{cm})$

$\mathrm{PR}=$ Protein $(\mathrm{g} / 100 \mathrm{~g})$
$\mathrm{CA}=\mathrm{Ca}(\mathrm{mg} / 100 \mathrm{~g})$

$\mathrm{IR}=\mathrm{Fe}(\mathrm{mg} / 100 \mathrm{~g})$

$\mathrm{PHE}=$ Phenols $(\mathrm{mg} / 100 \mathrm{~g})$

$\mathrm{OX}=$ Oxalates $(\mathrm{mg} / 100 \mathrm{~g})$

FYP=Genotypic correlation with foliage yield/plant 
As expected, plant height exhibited highly significant and positive association with stem girth, number of branches per plant, number of leaves per plant, spike length, number of spikes per plant and leaf area which are directly or indirectly contributing towards total foliage yield per plant. Hence, selection pressure on any one of these character would bring about improvement in all these yield traits. Similar results were noticed by Sarker et al., (2014), Roni (2013), Patial et al., (2014), Chattopadhyay et al., (2013), Diwan et al., (2017), Buhroy et al., (2017) and Sravanti (2011) and Panda (2015). The traits like hypocotyl length, iron content and oxalate content of leaves exhibited negative and significant association with plant height.

Stem girth showed highly significant and positive correlation with number of branches and leaves per plant, spike length, number of spikes per plant, leaf area and total foliage yield per plant while it showed significant and negative association with calcium, phenol and oxalate content of leaves. These results are in agreement with earlier findings of Sravanti (2011), Sarker et al., (2014), Hasan et al., (2013), Mandal et al., (2010), Diwan et al., (2017) Sarker et al., (2016) and Panda (2015).

Number of branches per plant showed highly significant and positive association with number of leaves per plant, spike length, number of spikes per plant, leaf area, foliage yield per plant while it showed significant and negative association with days to flower initiation, days to $50 \%$ flowering, calcium, phenol and oxalate content of leaves. Similar results were noticed by Varalakshmi and Devaraju (2010), Tejaswini et al., (2017) and Panda (2015).

Number of leaves per plant exhibited highly significant and positive association with foliage yield per plant followed by number of spikes per plant, spike length, leaf area and it also showed significant and negative association with hypocotyl length, phenol and oxalate content of leaves. These results are in agreement with previous findings of Sarker et al., (2014), Varalakshmi and Devaraju (2010), Jangde et al., (2017), Ahammed et al., (2012), Roni (2013), Chattopadhyay et al., (2013), Sarker et al., (2016) and Buhroy et al., (2017).

Spike length was positively and significantly associated with foliage yield per plant, leaf area, harvest index, number of spikes per plant and it was negatively and significantly associated with phenol content, calcium content, oxalate content and hypocotyl length of the plant. Similar results were obtained by Sravanti (2011) for seed yield per plant, Patial et al., (2014) for yield per plant and harvest index, Yashwanth (2009) for grain yield per plant in grain amaranth genotypes (Table 2).

Leaf area exhibited positive and significant association with foliage yield per plant, protein content of leaves and it was negatively correlated with oxalate content, hyopcotyl length and calcium content of leaves. Similar results were noticed by Sravanti (2011) for seed yield per plant in grain amaranthus, Sarker et al., (2014) for foliage yield per plot, Jangde et al., (2017) for leaf weight per plant. Protein content of leaves was significantly and positively associated with iron content and it was negatively associated with phenol content of leaves. However, it had nonsignificant positive association with foliage yield per plant. Similar result was noticed by Buhroy et al., (2017).

Genotypic correlation study indicated that the iron content and oxalate content of the leaves had no significant association with any other morphological or biochemical traits. However, phenol content of leaves had significant and negative association with foliage yield per plant. Singh (2010) reported that phenol content positively associated with 
grain yield per plant in grain amarathus species.

From the foregoing discussion, it is conceivable that a great deal of success can be achieved in improvement of foliage yield per plant by applying selection pressure on number of leaves per plant, number of branches per plant, leaf area, stem girth, spike length and number of spikes per plant as these traits had significant and positive correlation with foliage yield per plant.

\section{References}

Ahammed, A. U., Rahman, M. M. and Mian, M. A. K., 2012, Genetic variability, heritability and correlation in stem amaranthus (Amaranthus tricolor L.). Bangladesh J. Pl. Breed. Genet., 25 (2): 25-32.

Buhroy, S., Saraswathi, T. and Ramalingam, J., 2017, Genetic basis of yield and quality variations in vegetable amaranth (A. tricolor) to identify the promising genotypes. Int. J. Curr. Microbiol. App. Sci., 6(4): 2104-2111.

Burton, G. W. and Devane, E. M., 1952, Estimating heritability in tall fescue (Festuca circunclinaceae) from replicated clonal material. Agron. J., 45: 478-481.

Chattopadhyay, A., Das, S., Rana, N. P., Seth, T. and Dutta, S., 2013, Estimation of genetic parameters, inter-relationships and genetic divergence of vegetable amaranth. Int. J. Plant Breeding, 7(2): 111-115.

Diwan, I. S., Shukla, N. and Kurrey, V., 2017, Genetic studies in amaranthus germplasm. Int. J. Curr. Microbiol. App. Sci., 6(8): 2459-2470.

Grafius, J. E., 1959, Correlation and path analysis in barley. Agronomy Journal, 51: 551-554.

Harland, S. C., 1939, The genetics of cotton,
Jonathan cape, London. Pp.132.

Hasan, M., Akther, C. A. and Raihan, M. S., 2013, Genetic variability, correlation and path analysis in stem amaranth (Amaranthus tricolor L.) genotypes. Sci. J. Krishi Foundation., 11(1): 1-7.

Jangde, B., Asati, B. S., Sahu, P. and Tripathy, B., 2017, Correlation and path coefficient analysis in vegetable amaranthus (Amaranthus tricolor L.). J. Pharmacognosy and Phytochemistry., 1: 409-145.

Mandal, J., Dhangrah, V. K. and Bhat, J. S., 2010, Studies on genetic variability and trait interrelationship among morphological and phonological characters in vegetable amaranth. Crop. Res., 40(1, 2 \&3): 146-150.

Patial, M., Chauhan, A., Singh, K. P. and Sharma, D., 2014, Character association and path coefficient analysis in grain amaranth (Amaranthus spp.). Int. J. Agri. Env. and Biotech. 6(1): 101-106.

Panda, R. K., 2015, Variability studies in amaranthus, M.Sc. (Hort.) Thesis, Odisha Uni. Agri. and Tech., Bhubaneswar, India.

Rai, N. and Yadav, D. S., 2005, Advances in vegetable production. Research co Book Centre New Delhi, 530-531.

Roni, M. A., 2013, Morphological characterization and yield of forty nine stem amaranth germplasm. M.Sc. (Hort.) Thesis, Bangladesh Agri. Uni., Mymensingh,

Sankaran, A., 1943, Cultivation of leafy vegetables in the northern circars, Madras Agri. J., 31: 285-286.

Sarker, U., Islam, T., Rabbani, G. and Oba, S., 2014, Genotypic variability for nutrient, antioxidant, yield and yield contributing traits in vegetable amaranthus. Journal of Food, Agriculture and Environment, 12 (3):168-174. 
Sarker, U., Islam, T. Md., Rabbani, G. Md. and Oba, S., 2016, Genetic variation and interrelationships among antioxidant, quality, and agronomic traits in vegetable amaranth. Turk. $J$. Agric. For., 40: 526-535.

Singh, R., 2010, Genetic variability, diversity and stability analysis in grain amaranth (Amaranthus hypochondriacus L.). Ph.D. Thesis, Allahabad School of Agriculture, U.P. (India).

Sivasubramanian, S. and Menon, M., 1973, Heterosis and inbreeding depression in rice. Madras Agric. J., 60: 1139.

Sravanti, V., 2011, Genetic divergence studies in amaranthus, M.Sc. (Hort.) Thesis, Andra Pradesh Hort. Uni., (India).

Tejaswini, N., Saidaiah, P., Ravinder, R. K. and Ramesh, T., 2017, Correlation and path coefficient analysis in vegetable amaranth (Amaranthus tricolor L.) genotypes. Int. J. Curr. Microbiol. App. Sci., 6(6): 2977-2996.

Varalaksmi, B. and Devaraju, 2010, Genetic variability in Indian spinach (Basella alba L.), J. Hort. Sci., 5(1): 21-24.

Yashwanth K. M. S., 2009, Evaluation of grain amaranth (Amaranthus spp.) germplasm for genetic diversity under different seasons. M.Sc. (Hort.) Thesis, Univ. Agri. Sci. Bangalore (India).

\section{How to cite this article:}

Sagar, K.P., C.N. Hanchinamani, S.J. Imamsaheb, Sandhyarani Nishani and Ramanagouda, S.H. 2018. Genotypic Correlation Coefficients among Growth, Yield and Quality Parameters in Amaranthus Genotypes (Amaranthus tricolor L.). Int.J.Curr.Microbiol.App.Sci. 7(08): 27012707. doi: https://doi.org/10.20546/ijcmas.2018.708.282 